\title{
ABUNDANCE AND DIVERSITY OF PHYTOPLANKTON AT SEKOTONG BAY WATERS, WESTERN LOMBOK
}

\author{
Lalu Japa $^{1}$, Noar Muda Satyawan ${ }^{2 *}$, and Rizky Regina Kawirian ${ }^{3}$ \\ ${ }^{1}$ Biology Education Department, Faculty of Teacher Training and Education, \\ University of Mataram, Mataram, Indonesia \\ ${ }^{2}$ Capture Fisheries Department, Marine and Fisheries Polytechnic of Jembrana, Bali, Indonesia \\ ${ }^{3}$ Master Program in Water Resources Management, Bogor Agricultural University, Bogor, Indonesia \\ *Email: satyawan.nm@gmail.com
}

Accepted: November, 01 2021. Approved: November, 05 2021. Published: November, 122021

\begin{abstract}
Phytoplankton is one of the important components in aquatic ecosystems. This organism plays an important role as a primary producer to support the life of the tropics above it. The purposes of this study were to reveal the abundance and diversity of phytoplankton species in the waters of Sekotong Bay, West Lombok. Sampling were conducted in July 2018 at 8 stations using plankton net and then observed at the Laboratory. The results of the abundance calculations show a varied pattern at each observation station. The highest abundance was found at station 8 (9,060 ind/L) followed by station $6(8,300 \mathrm{ind} / \mathrm{L})$, station 7 (6,490 ind/L), station 4 (4,440 ind/L), station $3(3,980$ ind/L), station 5 (2,820 ind/L), station 2 (2,460 ind/L) and station 1 (2,440 ind/L). The Shannon - Wiener Species diversity Index also shows diverse patterns at each station. Station 7 has the highest diversity index value $\left(\mathrm{H}^{\prime}=3.55\right)$, followed by station $6\left(\mathrm{H}^{\prime}=3.46\right)$, station $8\left(\mathrm{H}^{\prime}=3.18\right)$, station $1\left(\mathrm{H}^{\prime}=2.72\right)$, station $2\left(\mathrm{H}^{\prime}=2.69\right)$, station $5\left(\mathrm{H}^{\prime}=\right.$ 2.67), station $4\left(\mathrm{H}^{\prime}=2.33\right)$ and station $3\left(\mathrm{H}^{\prime}=2.26\right)$. Species dominance index at all stations at low category with the highest dominance found at station $3(\mathrm{D}=0.19)$, followed by station $4(\mathrm{D}=0.18)$, station $2(\mathrm{D}=0.09)$, station 5 (D $=0$, 09), station $1(\mathrm{D}=0.08)$, station $8(\mathrm{D}=0.06)$, station $6(\mathrm{D}=0.05)$ and station $7(\mathrm{D}=0.04)$. Species Evennes index (E) values ranged from 0.71 to 0.88 , indicating that the number of individual species was relatively the same and the ecosystem was in relatively good condition. The analysis showed that the spatial pattern of abundance and diversity of phytoplankton species in Sekotong Bay was related to the distance from the estuary.
\end{abstract}

Keywords: Abundance, Diversity, Phytoplankton, Sekotong Bay, West Lombok

\section{INTRODUCTION}

Sekotong Bay is one of the bays in the administrative area of West Lombok. Settlements in the Sekotong area are getting busier as tourism is active in the area. Besides tourism, fishery activities such as fishing, fish farming with floating net cage systems, shrimp ponds and pearl oyster cultivation are sources of livelihood for the surrounding community. Along with the increase in community activities, sooner or later, an impact on the water quality in Sekotong Bay will be affected.

One of the organisms that its existence is highly dependent on water conditions is phytoplankton. Phytoplankton is a group of plants that are planktonic, living floating in the water column. Phytoplankton plays an important role in the absorption of carbon dioxide (CO2) and the production of oxygen which is needed for respiration for other organisms on earth. In addition, phytoplankton also plays an important role in the food chain of aquatic ecosystems, as primary producers that support life at the tropic level above it.

Community activities will produce residues or waste that will always end up in the sea. The waste can be in the form of $\mathrm{N}$ and $\mathrm{P}$ which are domestic waste from community settlements and agricultural activities. The elements $\mathrm{N}$ and $\mathrm{P}$ are the main elements needed for the growth and development of phytoplankton [1]. The ratio of $\mathrm{N}$ and $\mathrm{P}$ in the waters can trigger a phytoplankton population explosion. On the one hand, an increase in the phytoplankton population can provide benefits for the aquaculture sector because several types of phytoplankton are natural food for aquaculture biota. On the other hand, however, the population explosion can trigger a decrease in dissolved oxygen levels in the waters. Moreover, if a population explosion occurs in dangerous phytoplankton species or Harmful Alga Blooms (HABs), besides having a negative impact on aquatic biota, it has also a fatal impact on humans who consume these biota [2]. Therefore, this study aims at determining the abundance and diversity of phytoplankton species as the basis for managing aquatic resources in Sekotong Bay, West Lombok.

\section{RESEARCH METHODS \\ Research Site}

This research was conducted in the waters of Sekotong Bay which is the administrative area of West Lombok Regency in July 2018. Sampling was conducted at 8 observation stations spread across the Sekotong Bay area (Figure 1). 


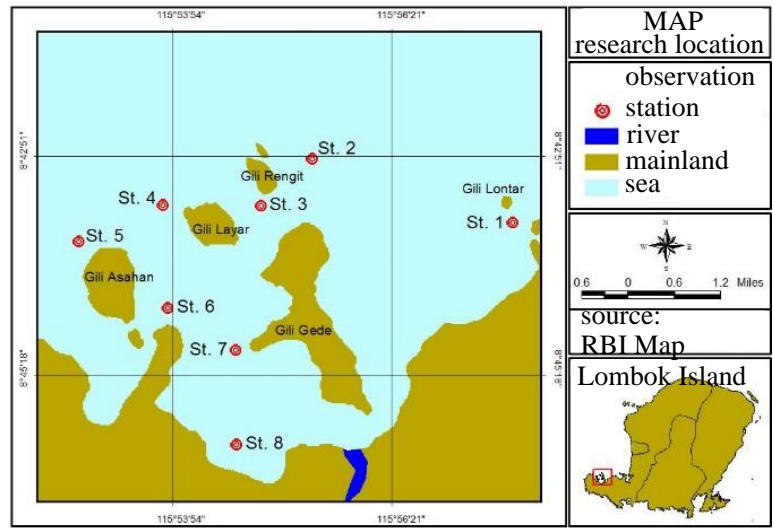

Figure 1. research location map

\section{Sampling and identification of phytoplankton}

Seawater samples were taken at each station as much as $100 \mathrm{~L}$ which then were filtered using plankton net No. 25 [3]. The filtering results were put into a sample bottle that had been labeled and then were preserved with $4 \%$ formalin. The preserved samples were observed under a microscope in the laboratory. The method used was the sweep method to count the number of individuals of each type of phytoplankton and was repeated 3 times. Identification of phytoplankton types was guided by [4].

\section{Phytoplankton Data Processing}

Phytoplankton data processing includes the calculation of abundance, diversity index, uniformity index and dominance index. The abundance of phytoplankton was determined quantitatively in the number of individuals/liter which was calculated based on the formula [3]:

$\mathrm{N}=$ number of cells per liter

$$
\mathrm{N}=\mathrm{n} \times(\mathrm{Vr} / \mathrm{Vo}) \times(1 / \mathrm{Vs})
$$

$\mathrm{n} \quad=$ Number of cells observed (individuals)

$\mathrm{Vr}=$ Sample volume $(\mathrm{ml})$

$\mathrm{V}_{\mathrm{o}}=$ Observed water volume $(\mathrm{ml})$

$\mathrm{Vs}=$ Volume of filtered water (L)

To measure the diversity index, the ShannonWiener $\left(\mathrm{H}^{\prime}\right)$ diversity index was used. The calculation of the uniformity index used the Evennes uniformity index formula (E), while the dominance used the Simpson dominance index (D). The formula used is as follows [3].

$$
\begin{array}{ll}
\mathrm{H}^{\prime}=-\sum_{H^{\prime}} \mathrm{Pi} \ln \mathrm{Pi} & \mathrm{Pi}=\mathrm{ni} / \mathrm{N} \\
\mathrm{P}=\frac{\mathrm{H}^{\prime} \text { maks }=\ln \mathrm{s}}{H^{\prime} \text { maks }} & \\
\mathrm{D}=(\mathrm{ni} / \mathrm{N})^{2} &
\end{array}
$$

Note:

ni $=$ Number of individuals of the $\mathrm{i}$-th species

$\mathrm{s} \quad=$ Number of species

$\mathrm{N}=$ Total number of individuals

\section{RESULTS AND DISCUSSIONS}

\section{Abundance of Phytoplankton Species}

Aquatic resources in their management efforts also include the establishment of an environmental system that supports each other's life at each trophic level in it. Phytoplankton is the most basic level in aquatic ecosystems. The role of phytoplankton as primary producers in waters makes it an important support for the trophic level above it. In addition to these roles, phytoplankton can also be used as bioindicators of water quality. The existence of the type and abundance of phytoplankton provides an overview of the condition of the ecosystem in the aquatic environment.

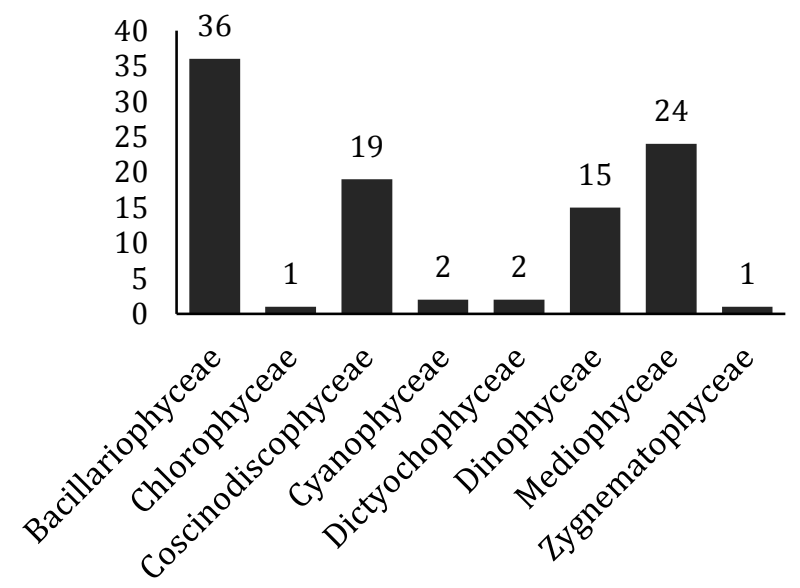

Figure 2. Number of species of each class of phytoplankton found in Sekotong Bay

Figure 2 shows the number of species of each phytoplankton found in the waters of Sekotong Bay. Based on the results of observations, 100 species of phytoplankton were generally found, and belong to 8 classes. The Bacillariophyceae class has the highest number of species (36 species), followed by Mediophyceae (24 species), Coscinodiscophyceae (19 species), Dinophyceae (15 species), Cyanophyceae (2 species), Dictyochophyceae (2 species), Chlorophyceae (1 species) and Zygnematophyceae. (1 species). The number of species found was more compared to the results of other surveys. As reported by [5] who found $22-24$ species of phytoplankton in the pearl oyster culture area in Sekotong Bay. A total of 20 phytoplankton species in Kodek Bay, North Lombok [6]. The abundance and composition of phytoplankton can describe water conditions and is closely related to changes in water quality [7].

Phytoplankton of the Bacillariophyceae class was found in the highest number of species compared to other classes found in the waters of Sekotong Bay. The class Bacillariophyceae was previously reported to dominate the phytoplankton community in the waters of Lombok and Sumbawa islands [8], [9]; [10]; [11]. This shows that this class has a wide distribution. The composition of phytoplankton in the sea is 
dominated by the class Bacillariophyceae or diatoms. In addition, diatoms also have the ability to adapt to the environment, are cosmopolitan, resistant to extreme conditions and have high reproductive power [12]. Diatoms can reproduce three times in 24 hours when there is an increase in nutrient concentrations [13]. Phytoplankton of the Bacillariophyceae class has a very fast response to the addition of nutrient concentrations in the waters [14].

Besides Bacillariophycea, the class of phytoplankton that has a relatively large number of species is Dynophyceae. Phytoplankton from the Dynophyceae class is known to be dangerous in the event of a population explosion (blooming) or popularly known as Harmful Algal Blooms (HABs). Some of the potentially dangerous Dynophyceae species are those from the genera Ceratium, Peridinium and Dynophysis. Dinophyceae are known to produce five types of toxins, i.e. Paralytic Shellfish Poisoning (PSP), Diarrhetic Shellfish Poisoning (DSP), Neurotoxic Shellfish Poisoning (NSP), Amnesic Shellfish Poisoning (ASP), and Ciguatera Fish Poisoning (CFP) [15].

Ceratium is always dominant in tropical waters that have fluctuations in nutrients such as in Indonesia [2]. The population explosion of Ceratium resulted in reduced levels of $\mathrm{O} 2$ in the waters which resulted in the mass death of marine organisms [16]. Besides Ceratium, the most poisonous species of Dinophyceae is Dinophysis. This species is known to produce dinophysistoxin which is the cause of Diarrhetic Shellfish Poisoning (DSP) disease [17]. This disease is not lethal, but has a latent danger of accumulation which in turn can be hepatotoxic, immuno-suppressive and tumor-promoting [18].

Dinophyceae is a class of phytoplankton which its existence needs to be aware of in an aquatic ecosystem. The abundance of Dinophyceae is highly dependent on the nutrient ratio [19]. Anderson et al. (2002) reported that Dinophyceae grew optimally at an $\mathrm{N}: \mathrm{P}$ ratio more than $16: 1$. The high nutrient content indirectly changes the species composition of phytoplankton, including the dominant diatom species into Dinoflagellates [20]. Population explosion (blooming) of Dinophyceae occurs when the dilution rate is reduced and light penetration and salinity increase [21]

The abundance of phytoplankton varied at each observation station (Figure 3). The highest abundance was found at station 8 with 9,060 individuals/L, followed by station $6 \quad(8,300$ individuals/L), station 7 (6,490 individuals/L), station $4 \quad(4,440 \quad$ individuals/L), station $3 \quad(3,980$ individuals/L), station 5 (2,820 individuals/L), station 2 (2,460 individuals/L) and station $1 \quad(2,440$ individuals/L). The abundance of phytoplankton found in Sekotong Bay was relatively higher than the observations at other locations on the island of
Lombok. The abundance of phytoplankton found in Kodek Bay, North Lombok is 6,557 individuals/L [6].
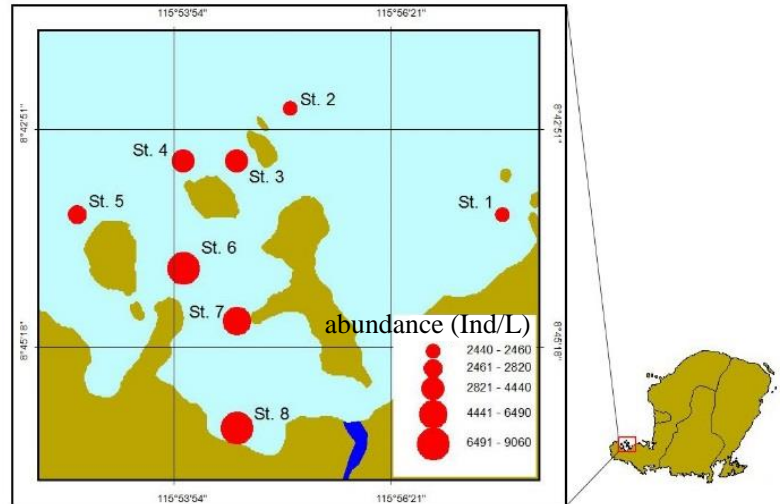

Figure 3. Distribution map of the abundance of phytoplankton in the waters of Sekotong Bay

The value of the abundance of phytoplankton is influenced by the parameters of the aquatic environment that support the growth and development of phytoplankton. The determining factor that affects the abundance of phytoplankton is the content of nitrate and nitrite in the waters. This is consistent with what was reported by [1] that optimal growth of phytoplankton requires nitrate content in the range of $0.9-3.5 \mathrm{mg} / \mathrm{L}$ and orthophosphate $0.09-1.80 \mathrm{mg} / \mathrm{L}$. In addition, phytoplanton from the diatom group requires silica to develop properly. The abundance of diatoms $38 \%$ is influenced by the concentration of silica in the water [22].

The distribution map of the abundance of phytoplankton at each station in the waters of Sekotong Bay shows a higher tendency as it approaches the river mouth. This is probably caused by the accumulation of nutrients from river run-off and mangrove ecosystems around the estuary. This accumulation causes stations 6,7 and 8 to be rich in nutrients that strongly support the growth and development of phytoplankton. In contrast to stations $1,2,3,4$ and 5 which are located on the outside of the bay and are quite far from the estuary and experience flushing which reduces the concentration of nutrients in the waters so that the abundance of phytoplankton is not as high as stations close to the river mouth.

\section{Phytoplankton Ecological Index}

The results of the calculation of the ecological index of phytoplankton found in the waters of Sekotong Bay are presented in Table 1. The calculation results show that the diversity index $\left(\mathrm{H}^{\prime}\right)$ varies at each observation station. The highest diversity index value was obtained at station 7 $\left(\mathrm{H}^{\prime}=3.55\right)$ followed by station $6\left(\mathrm{H}^{\prime}=3.46\right)$, station 8 $\left(\mathrm{H}^{\prime}=3.18\right)$, station $1\left(\mathrm{H}^{\prime}=2.72\right)$, station $2\left(\mathrm{H}^{\prime}=2,69\right)$, station $5\left(\mathrm{H}^{\prime}=2,67\right)$, station $4\left(\mathrm{H}^{\prime}=2,33\right)$, and station 3 $\left(H^{\prime}=2.26\right)$. Phytoplankton diversity index in Sekotong Bay is in the medium category. This shows that the 
phytoplankton community found in the waters of Sekotong Bay is included in the category of moderate stability.

The results of the calculation of the uniformity index $(\mathrm{E})$ ranged from $0.71-0.88$. The highest uniformity index value was found at station 1 $(\mathrm{E}=0.88)$ followed by station $2(\mathrm{E}=0.86)$, station 5 $(\mathrm{E}=0.86)$, station $6(\mathrm{E}=0.86)$, station $7 \quad(\mathrm{E}=0.82)$, station $8(\mathrm{E}=0.81)$, station $4(\mathrm{E}=0.74)$ and station 3 $(\mathrm{E}=0.71)$. The uniformity index shows that the distribution between genera is relatively uniform or the number of individuals of each genera is relatively the same. This is illustrated by the low dominance index value at each observation station. The highest dominance index value was found at station 3 $(\mathrm{D}=0.19)$, followed by station $4(\mathrm{D}=0.18)$, station 5 $(\mathrm{D}=0.09)$, station $2(\mathrm{D}=0.09)$, station $1(\mathrm{D}=0.08)$, station $8(\mathrm{D}=0.06)$, station $6(\mathrm{D}=0.05)$ and station 7 $(\mathrm{D}=0.04)$. The low value of the dominance index indicates that there are no phytoplankton species classified as dominant in the waters of Sekotong Bay.

Table 1. Calculation of the ecological index of phytoplankton in the waters of Sekotong Bay

\begin{tabular}{cccccc}
\hline Station & $\sum$ & $\begin{array}{c}\mathrm{N} \\
\text { species }\end{array}$ & $\begin{array}{c}\text { (Ind/L) } \\
\mathrm{H}^{\prime}\end{array}$ & $\mathrm{E}$ & $\mathrm{D}$ \\
\hline 1 & 22 & 2.440 & 2,72 & 0,88 & 0,08 \\
2 & 23 & 2.460 & 2,69 & 0,86 & 0,09 \\
3 & 24 & 3.980 & 2,26 & 0,71 & 0,19 \\
4 & 23 & 4.440 & 2,33 & 0,74 & 0,18 \\
5 & 22 & 2.820 & 2,67 & 0,86 & 0,09 \\
6 & 57 & 8.300 & 3,46 & 0,86 & 0,05 \\
7 & 76 & 6.490 & 3,55 & 0,82 & 0,04 \\
8 & 51 & 9.060 & 3,18 & 0,81 & 0,06 \\
\hline
\end{tabular}

Phytoplankton species included in the subdominant (general) category found in the waters of Sekotong Bay were Bacillaria paradoxa, Fragilaria oceanica, Nitzschia pacifica, Rhabdonema adriaticum, Coscinodiscus centralis, Chaetoceros decipiens, Leptocylindrus minimus (Figure 4). The diatom species found in Sekotong Bay are natural food for fish. One of the species that are popular for mass culture as food for Rotiera, clams, pearl oysters and shrimp larvae are from the genus Chaetoceros [6].

The phytoplankton species found at all observation stations were Trichodesmium erythraeum and Surirella cuneata. This shows that these two species have a wide distribution in the waters of Sekotong Bay. Trichodesmium erythraeum plays an important role in the fixation of nitrogen and carbon dioxide from the atmosphere, but on the other hand it is a phytoplankton species from the Cyanophyceae class which is classified as dangerous algae (HABs) [23]. Phytoplankton community structure will be affected by toxins produced by Trichodesmium which are allopathic.

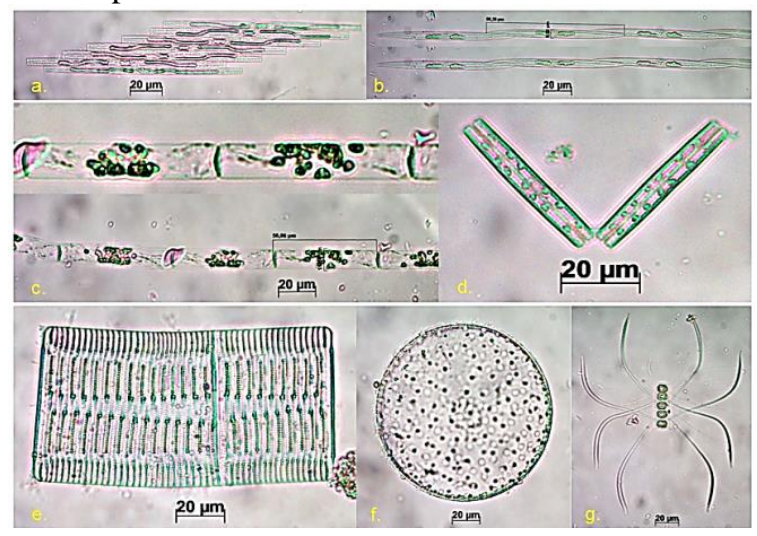

Figure 4. Phytoplankton species found sub dominant (general) in the waters of Sekotong Bay (a. Bacillaria paradoxa; b. Nitzschia pacifica; c. Leptocylindrus minimus; d. Fragilaria oceanica; e. Rhabdonema adriaticum; f. Coscinodiscus centralis; g. Chaetoceros decipiens)

Population explosion (blooming) of Trichodesmium often occurs in several areas in Indonesia. In addition to nutrient enrichment in the waters, high salinity is also a triggering factor for population explosions, so that it often occurs in waters that are located parallel to the shoreline and slightly to the center [2]. Trichodesmium population explosion are reported to be harmful to fish and shellfish [24]. Fatal incidents in shrimp ponds, aquaculture and coral reefs have occurred in Indonesia [2]. Continuous monitoring efforts are needed to be aware of the emergence of a phytoplankton species population explosion in order not to cause fatal losses.

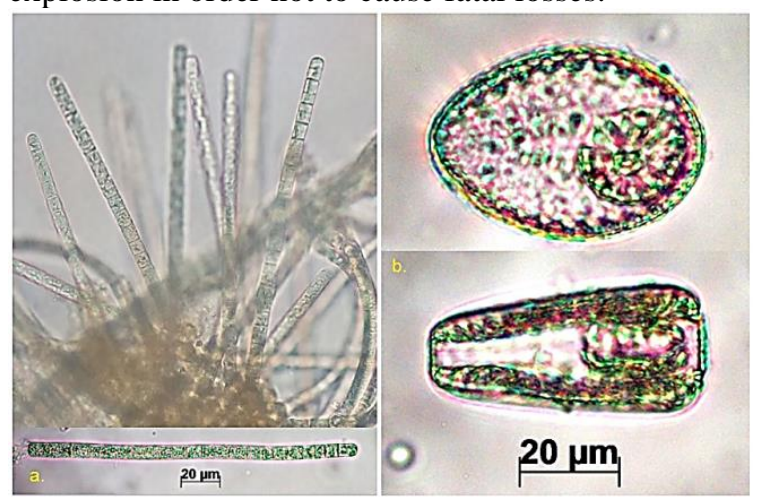

Figure 5. Phytoplankton species found at all observation stations (a. Trichodesmium erythraeum; b. Surirella cuneata)

\section{CONSLUSION}

Based on the results of observations and discussions, it can be concluded that the abundance of phytoplankton in the waters of Sekotong Bay ranges from 2,440 - 9,060 ind/L. The index of phytoplankton species diversity in the waters of Sekotong Bay is in 
the medium category with a low dominance index. The value of the species uniformity index ranged from 0.71 to 0.88 which indicated that the number of individual species was relatively the same and the ecosystem was in relatively good condition. The spatial distribution pattern of the abundance and diversity of phytoplankton species in Sekotong Bay is probably related to the distance from the estuary.

\section{REFERENCES}

[1] Handoko, M.Y. dan Y.W. Sri. (2013). Sebaran nitrat dan fosfat dalam kaitannya dengan kelimpahan fitoplankton di kepulauan Karimunjawa. Jurnal Oseanologi. 2(3):198-206.

[2] Thoha, H. (1991). Ledakan Populasi Trichodesmium erythraewn. Oseana. 16(3):9-15.

[3] Fachrul, M. F. (2008). Metode Sampling Bioekologi. Jakarta : PT Bumi Aksara.

[4] Yamaji, I. (1976). Illustration of the marine plankton of Japan. Tokyo.: Hoikusha Publishing Co. Ltd.

[5] Fathurrahman\& Aunurohim. (2014). Kajian Komposisi Fitoplankton dan Hubungannya dengan Lokasi Budidaya Kerang Mutiara (Pinctada Maxima) di Perairan Sekotong, Nusa Tenggara Barat. Jurnal Teknik Pomits. 3(2):9398.

[6] Cokrowati, N., Amir, S., Abidin, Z., Setyono, BDH., dan Damayanti, AA. (2014). Kelimpahan dan komposisi fitoplankton di perairan Teluk Kodek Pemenang Lombok Utara. Depik. 3(1):2126.

[7] Munthe, Y.V., A. Riris dan Isnaini. (2012). Struktur komunitas dan sebaran fitoplankton di perairan Sungsang Sumatera Selatan. Maspari Journal. 4(1):122-130.

[8] Japa, L. dan Karnan. 2007. Studi Komunitas Fitoplankton Di Perairan Pantai Kota Mataram. Jurnal Biologi Tropis. 8(1):7-12.

[9] Komalasari, E., K. Khairuddin, dan L. Japa. 2019. The Diatom Community in Maluk Coastal Water in West Sumbawa. Proceeding of the Fist Annual Conference on Education and Social Sciences (ACCESS). Advances in Social Science, Education and Humanities Research, volume 465. Atlantis Press.

[10] Khairuddin dan L. Japa. 2014. Komunitas Plankton Perairan Pantai Utara, Timur, dan Selatan Pulau Lombok, Jurnal Biologi Tropis. 14(2):100-107.

[11] Aini Y.Q., A. Al Idrus, dan L. Japa. 2018. Komunitas Plankton pada Perairan Habitat Mangrove di Gili Sulat Lombok Timur. Prosiding Seminar Nasional Pendidikan Biologi. 32-40.

[12] Nybakken, J. W. (1992). Biologi Laut Suatu Pendekatan Biologis. PT Gramedia. Jakarta
[13] Praseno, D,P. dan Sugestiningsih. (2000). Red tide di perairan Indonesia. Jakarta: Pusat Penelitian dan Pengembangan Oseanologi - LIPI.

[14] Nybakken, J. W., and M. D. Bertness. (2005). Marine biology : An ecological approach 6th ed.USA. Pearson Education Inc.

[15] Burkholder, J.M. (1998). Implications of harmful microalgae and heterotrophic dinoflagellates in management of sustainable marine fisheries. Ecological applications. 8:37-62.

[16] Mulyani, Riani, W., Wisnu W. (2012). Sebaran Spasial Spesies Penyebab Harmful Algal Blooms (HABs) di Lokasi Budidaya Kerang Hijau (Perna viridis) Kamal Muara, Jakarta Utara pada Bulan Mei 2011. Jurnal Akuatika. 3(1):28-39.

[17] Panggabean, L.M.G. (2006). Toksin Alam Dari Mikroalgae. Jurnal Oceana. 31(3): 1-2.

[18] Aune, T. and Yndestad, M. (1993). Diarrhetic shellfish poisoning. In : I.R. Falconer (ed.), Algal Toxins in Seafood and Drinking Water. London. Academic Press.

[19] Hauss, H., J.M. Franz, and U. Sommer. (2012). Changes in N: P stoichiometry influence taxonomic composition and nutritional quality of phytoplankton in the Peruvian upwelling. $J$. of sea Research. 73:74-85.

[20] Alonso-Rodriguez R,. dan F. Paez-Osuna. (2003). Nutriens, phytoplankton and harmful algal blooms in shrimp ponds: a review with special reference to the situation in the Gulf of California. Aquaculture. 219(1):317- 336.

[21] Harrison, P.J. (2000). Dynamics of nutriens and phytoplankton biomass in the Pearl River estuary and adjacent waters of Hong Kong during summer: preliminary evidence for phosphorus and silicon limitation. Mar. Ecol. Prog. Ser. 194:295-305.

[22] Umiatun, S., Carmudi, Christiani. (2017). Hubungan Antara Kandungan Silika Dengan Kelimpahan Diatom Benthik Di Sepanjang Sungai Pelus Kabupaten Banyumas. Scripta Biologica. 4(1): 61-67.

[23] Capone DG, Zehr JP, Paerl HW, Bergman B, Carpenter EJ. (1997). Trichodesmium, a globally significant marine cyanobacterium. Science. 276:1221-1229.

[24] Bhat, S.R. and Verlencar, X.N. (2006). Some enigmatic aspects of Marine Cyanobacterial genus, Trichodesmium. Current. Sci. 91:18-1. 